Ann. Biol. anim. Bioch. Biophys., 1979, 19 (3 B), 775-780.

\title{
Intestinal handling of iron and calcium in idiopathic haemochromatosis: new data and therapeutic perspectives
}

\author{
par L. MONNIER $\left({ }^{1}\right)$, C. COLETTE, C. RIBOT **, J. MIROUZE \\ Department of Metabolism and Endocrine Diseases. \\ Saint Eloi Hospifal, 34059 Montpellier Cedex. \\ ** Department of Experimental Medicine, UER Toulouse-Purpan \\ Toulouse, France.
}

\begin{abstract}
Summary. The fractional intestinal absorption of iron (FAFe), i.e. p. 100 of the total dose (p. 100 TD), was measured in 13 patients with idiopathic haemochromatosis in two situations : in basal conditions (after fasting), and following an oral indigestible fiber load with either pectin (group I, 8 cases) or cellulose (group II, 5 cases). The results obtained were compared to those found in 7 controls investigated in basal conditions. Calcium homeostasis was evaluated in 9 haemochromatic patients (group III) and in 10 controls using the following parameters : (i) fractional intestinal absorption of calcium (FA Ca, p. $100 \mathrm{TD}$ ) ; (ii) bone mineral content $\left(\mathrm{BMC}, \mathrm{mg} / \mathrm{cm}^{2}\right.$ ) ; (iii) plasma $25-\mathrm{OH}$ vitamin D content (25-OH-D, ng/ml). Results. The basal FA Fe significantly increased in haemochromatic patients as compared with the control subjects. In group I, pectin produced a significant decline in FA Fe $(25.5+5.0$ vs $47.6+9.2$ in basal conditions : $P<0.02)$. On the contrary, cellulose has no significant effect on FA Fe. In group III, FA Ca $(P<0.02), B M C$ $(P<0.05)$ and $25-\mathrm{OH}-\mathrm{D}(\mathrm{P}<0.01)$ significantly dropped as compared with the controls. The present results suggested that fiber-supplemented diets might be useful in the management of haemochromatosis. Furthermore, the osteopenia of haemochromatosis seemed to be due to a deficiency in $25-\mathrm{OH}$ cholecalciferol production. Therefore, a supplement of the latter might be useful in preventing bone mass rarefaction.
\end{abstract}

\section{Introduction.}

Idiopathic haemochromatosis is usually characterized by high rates of intestinal iron absorption. On the other hand, the absorption of such divalent ions as calcium or magnesium is diminished by oral indigestible fiber intake (Heaton and Pomare, 1974 ; Reinhold ef al., 1976). In this report, we have studied the effects of pectin and cellulose on iron absorption in haemochromatic patients. Calcium homeostasis in these patients

(1) Reprint requests should be addressed to Dr. L. Monnier-Department of Metabolism and Endocrine Diseases. Saint Eloi Hospital, 34059 Monfpellier Cedex. France. 
is discussed in the second part of the report in an atfempt to clarify the mechanism and treatment of osteoporosis, frequently encountered in the course of idiopathic haemochromatosis (Delbarre, 1960).

\section{Material and methods.}

The effects of indigestible fibers on iron absorption were studied in 13 patients suffering from idiopathic haemochromatosis. Iron absorption measured in basal conditions, i. e. after overnight fasting, was compared with absorption after an oral intake $\left(9 \mathrm{~g} / \mathrm{m}^{2}\right.$ of body surface) of either pectin (group I, 8 cases) or microcrystalline cellulose (group II, 5 cases). The results were compared to those of 7 controls who were studied in basal conditions. Intestinal iron absorption was determined by a double radiotracer technique (Cook and Lipschitz, 1977). Each subject was simultaneously given $5 \mu \mathrm{Ci}$ of transferrin-bound radioactive ferric iron $\left({ }^{55} \mathrm{Fe}\right.$, Saclay, France) by intravenous route, and $10 \mu \mathrm{Ci}$ of ${ }^{59} \mathrm{FeCl}_{2}$ (Saclay, France) orally with $1 \mathrm{mg}$ of non-radioactive iron such as ferrous chloride. By applying the mathematical procedure of inverse convolution (Shipley and Clark, 1972) to the appearance/disappearance curves of plasma ${ }^{59} \mathrm{Fe}$ and ${ }^{55} \mathrm{Fe}$ activities, we obtained the time curve of oral iron transit from the gut lumen to the plasma. Four main parameters were computed from this curve : $(a)$ the fraction of oral radioiron absorbed at completion of the absorptive process, $i$. e. fractional absorption (FAFe) expressed as a percentage of the total oral dose (p.100 TD), (b) peak absorption rate (p. $100 \mathrm{TD} / \mathrm{min}$ ), (c) time of peak absorption rate (min), (d) mean transit time across the intestinal barrier.

Calcium homeostasis was evaluated in 9 diabetic patients with idiopathic haemochromatosis using the following criteria : (i) intestinal calcium absorption, measured by a double radiotracer technique (i. v. ${ }^{45} \mathrm{CaCl}_{2}$ and oral ${ }^{47} \mathrm{CaCl}_{2}$ ) similar to that used for iron absorption measurement (Birge et al., 1969 ; Monnier ef al., 1978) : the 4 main parameters were obtained for fractional absorption of calcium (FA Ca), expressed as a percentage of the total oral dose (p. 100 TD) ; (ii) bone mineral content (BMC, $\mathrm{mg} / \mathrm{cm}^{2}$ ), determined on the forearm by Cameron's absorptiometric technique (Cameron and Sorenson, 1963) ; (iii) plasma 25 hydroxyvitamin D level $(25-\mathrm{OH}-\mathrm{D}, \mathrm{ng} / \mathrm{ml})$, measured by a radiocompetitive binding radioassay (Preece ef al., 1974). The results were compared to those found in 10 controls and 8 diabetics without haemochromatosis.

\section{Results.}

Effects of indigestible fibers on iron absorption.

Group 1 : Effect of pectin. As indicated on table 1, patients with haemochromatosis had a significantly higher basal FAFe than the controls. Although this basal parameter still remained higher than normal after pectin intake, the pectin induced a significant drop of FAFe in the haemochromatic patients.

Group II. Effect of cellulose. In the 5 patients of group II investigated for cellulose effects, FAFe and the other parameters of iron absorption remained unchanged after 
cellulose intake (table 1). As in group I the haemochromatic patients were characterized by a significant increase in basal FAFe.

\section{TABLE 1}

Comparison of parameters of intestinal iron absorption in different groups of haemochromatic patients and in control subjects.

\begin{tabular}{|c|c|c|c|c|c|}
\hline \multirow[b]{3}{*}{ No. tested } & \multicolumn{2}{|c|}{$\begin{array}{l}\text { Patients } \\
\text { with haemochromatosis } \\
\text { (group l) }\end{array}$} & \multirow{2}{*}{$\begin{array}{l}\text { Control } \\
\text { Subjects }\end{array}$} & \multicolumn{2}{|c|}{$\begin{array}{l}\text { Patients } \\
\text { with haemochromatosis } \\
\text { (group II) }\end{array}$} \\
\hline & \multicolumn{2}{|c|}{$\begin{array}{c}\text { before after } \\
\text { a pectin load }\end{array}$} & & $\begin{array}{l}\text { before } \\
\text { a cellu }\end{array}$ & $\begin{array}{l}\text { after } \\
\text { load }\end{array}$ \\
\hline & 8 & 8 & 7 & 5 & 5 \\
\hline $\begin{array}{l}\text { Fractional absorption of iron } \\
\text { (p. } 100 \text { total dose) }\end{array}$ & $\begin{array}{r}47.6 \\
\therefore \quad 9.2 \\
4\end{array}$ & 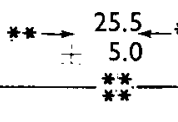 & $\begin{array}{r}7.0 \\
\because \quad 2.3 \\
4\end{array}$ & $\begin{array}{r}32.3 \\
\pm \begin{array}{r}8.6 \\
\pm *\end{array} \\
\end{array}$ & $\begin{array}{r}30.7 \\
-\quad 6.7 \\
\end{array}$ \\
\hline $\begin{array}{l}\text { Peak absorption rate } \\
\text { (p. } 100 \text { total dose } / \mathrm{min})\end{array}$ & $\therefore \begin{array}{l}1.22 \\
0.37 \\
4\end{array}$ & $\begin{array}{l}0.56 \\
0.10 \\
* * \\
\end{array}$ & $\rightarrow \begin{array}{r}0.14 \\
0.04 \\
4\end{array}$ & $\begin{array}{r}-\quad 0.59 \\
\therefore \quad 0.19 \\
+\end{array}$ & $\begin{array}{r}0.58 \\
+\quad 0.14 \\
\end{array}$ \\
\hline $\begin{array}{l}\text { Time of peak absorption } \\
\text { rate (min) }\end{array}$ & $\begin{array}{r}30.0 \\
\therefore \quad 8.5\end{array}$ & $\begin{array}{r}28.1 \\
+: \quad 5.6\end{array}$ & $\begin{array}{r}24.6 \\
. \quad 4.8\end{array}$ & $\begin{array}{r}34.5 \\
\therefore \quad 5.6\end{array}$ & $\begin{array}{r}34.5 \\
1 . \quad 7.3\end{array}$ \\
\hline $\begin{array}{l}\text { Mean transit time } \\
(\mathrm{min})\end{array}$ & $\begin{array}{r}40.7 \\
-:-8.3\end{array}$ & $\begin{array}{r}38.2 \\
\quad 5.5\end{array}$ & $\begin{array}{r}35.3 \\
+\quad 4.3\end{array}$ & $\begin{array}{r}54.0 \\
\vdots \quad 9.6\end{array}$ & $\begin{array}{r}52.5 \\
-\quad 8.2\end{array}$ \\
\hline
\end{tabular}

All results are given as mean \pm SEM. Statistical differences are only indicated when significant. $\left({ }^{*}\right) \mathrm{P}<0.05,\left({ }^{* *}\right) \mathrm{P}<0.02,\left({ }^{* * *}\right) \mathrm{P}<0.01,(* * * *) \mathrm{P}<0.001$

Calcium homeostasis. - Intestinal calcium absorption, estimated from fractional absorption and peak absorption rates, decreased in patients with haemochromatosis as compared to diabetic subjects without haemochromatosis and the controls. As shown on table 2, statistical differences were particularly marked when the fractional absorption values and peak absorption rates of patients and controls were compared. Bone mineral content was significantly lower in patients with haemochromatosis than in controls, while no difference was found between controls and diabetic patients without haemochromatosis (table 2). Plasma 25-OH-D levels significantly diminished in subjects suffering from haemochromatosis as compared with controls and diabetics without haemochromatosis (table 2).

\section{Discussion.}

Effects of indigestible pectin and cellulose on iron absorption.

The present results show that pectin produced a significant drop, and thus exerted a beneficial effect on the intestinal absorption of iron. Cellulose, on the other hand, did 
TABLE 2

Comparison of intestinal calcium absorption, bone mineral content and plasma 25 hydroxyvitamin $D$ in the various groups of patients and in control subjects.

\begin{tabular}{|c|c|c|c|}
\hline & \multirow[b]{2}{*}{$\begin{array}{l}\text { Control } \\
\text { Subjects }\end{array}$} & \multicolumn{2}{|c|}{ Diabetic pafients } \\
\hline & & $\begin{array}{c}\text { With } \\
\text { haemochromatosis } \\
\text { (group I) }\end{array}$ & $\begin{array}{l}\text { Without } \\
\text { haemochromatosis } \\
\text { (group II) }\end{array}$ \\
\hline $\begin{array}{l}\text { Parameters of intestinal } \\
\text { calcium absorption } \\
\text { (No. tested) } \\
\text { Fractional absorption } \\
\text { of Ca (p. } 100 \text { total dose) } \\
\text { Peak absorption rate } \\
\text { (p. } 100 \text { total dose/min) } \\
\text { Time of peak absorption rate } \\
\text { (min) } \\
\text { Mean transit time (min) }\end{array}$ & $\begin{array}{c}(10) \\
64.0 \\
+\quad 2.7 \\
1.2 \\
0.14 \\
33.0 \\
+\quad 7.2 \\
59.4 \\
+\ldots 12.2\end{array}$ & 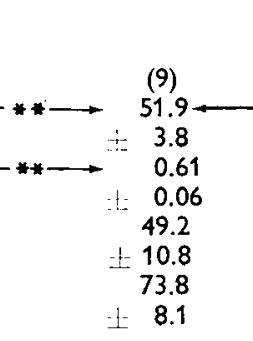 & $\begin{array}{c}(8) \\
\quad 64.2 \\
-\quad 6.5 \\
0.73 \\
0.12 \\
28.1 \\
: \pm \quad 6.3 \\
74.9 \\
-. \quad 12.4\end{array}$ \\
\hline $\begin{array}{l}\text { Plasma } 25 \text { hydroxyvitamin D } \\
(\mathrm{ng} / \mathrm{ml}) \\
\text { (No. tested) }\end{array}$ & $\begin{array}{r}16.4 \\
- \pm \\
1.3 \\
(10)\end{array}$ & $-\begin{array}{c}5.3 \\
0.6 \\
(7)\end{array}$ & $* \begin{array}{r}14.3 \\
3.5 \\
(5)\end{array}$ \\
\hline $\begin{array}{l}\text { Bone mineral content } \\
\left(\mathrm{mg} / \mathrm{cm}^{2}\right) \\
\text { (No. tested) }\end{array}$ & $\begin{array}{r}879 \\
26 \\
(10)\end{array}$ & $\longrightarrow \begin{array}{c}784 \\
\pm \begin{array}{c}45 \\
(8)\end{array}\end{array}$ & $\begin{array}{r}890 \\
+\quad 26 \\
(6)\end{array}$ \\
\hline
\end{tabular}

All results are given as mean \pm SEM. Statistical differences are only indicated when significant. $* \mathbf{P}<0.05 ; * * \mathrm{P}<0.02 ; * * * \mathbf{P}<0.01$.

not appear to have any effect on iron transfer across the intestine. The differences observed between the effects of pectin and those of cellulose might be explained by the mechanism of action of these substances, which cause the formation of unabsorbable complexes with intraluminal ferrous iron (Bjorn-Rasmussen, 1974 ; Reinhold ef al., 1975 ; Ismail Beiji, Faradji and Reinhold, 1977). As previously demonstrated, cellulose possesses a smaller binding capacity for divalent ions than pectin (Ismail Beiji, Faradji and Reinhold, 1977). It is therefore reasonable to suppose that pectin, rather than cellulose, would decrease iron absorption by inhibiting iron uptake by the duodenal cells.

\section{Colcium homeostasis.}

Intestinal calcium absorption, bone mineral mass and plasma 25-OH-D levels significantly diminished in diabetic patients suffering from haemochromatosis as compared with control subjects and diabetic patients without haemochromatosis. Furthermore, intestinal calcium absorption, bone mass and plasma 25-OH-D levels 
were similar in the controls and in diabefics without haemochromatosis. According to the present results, it seemed unlikely that alterations of calcium homeostasis, as observed in haemochromatic patients, were due only to the diabetic state. On the contrary, our data indicate that the impairment of calcium balance is probably explained by metabolic abnormalities directly related to the iron storage disorder. The significant drop in plasma 25-OH-D noted in our haemochromatic patients, seemed to suggest that haemochromatosis is characterized by a reduction of hepatic 25-hydroxycholecalciferol production (Blunt, De Luca and Schnoes, 1968 ; De Luca, 1974). This metabolic abnormality would lead to decreased intestinal calcium absorption (Wills, 1973) and, in turn, to bone mass rarefaction.

\section{Conclusion.}

The use of pectin-supplemented diets may be a useful adjunct to repeated phlebotomy which is the standard therapy in haemochromatosis. However, this supplementation may worsen (Heaton and Pomare, 1974) calcium absorption, which is already low in idiopathic haemochromatosis. For tha reason, a d because our results provide evidence for $25-\mathrm{OH}$ vitamin $\mathrm{D}$ deficiency, we recommend 25-hydroxycholecalciferol supplementation in the treatment of haematochromatic patients. Furthermore, plasma 25-OH-D levels should be individually and periodically checked to ensure that the treatment is both effective and has no side effects due to overdosage.

Commission CNERNA Digestion-Absorption/Association des Physiologistes, Paris 5-6 octobre 1978.

Acknowledgments. - The authors are indebted to Dr. H. Collef, Mrs B. Serrano and Miss M. C. Testor for their skilled technical assistance.

Résumé. L'absorption fractionnelle du fer (AFFe), p. 100 de dose tolale (p. 100 DT), est mesurée chez 13 malades ayant une hémochromatose idiopathique, dans deux conditions : $(a)$ à l'état de base, c'est-à-dire à jeun et $(b)$ après une charge orale en fibres indigestibles sous forme de pectine (groupe I: 8 cas) ou de cellulose (groupe II: 5 cas). Les résultats obtenus sont comparés à ceux trouvés chez 7 témoins explorés à l'élat de base. Chez 9 hémochromatosiques (groupe III) et chez 10 témoins, l'homéostasie calcique est évaluée grâce aux paramètres suivant : (a) l'absorption fractionnelle du calcium (AFCa, p. 100 DT) (b) le contenu minéral de l'os $\left(\mathrm{CMO}, \mathrm{mg} / \mathrm{cm}^{2}\right)$; (c) la $25 \mathrm{OH}$ vitamine D (25-OH-D, $\mathrm{ng} / \mathrm{ml}$ ). Résultats : l'AFFe de base est significativement augmentée chez les hémochromatosiques par rapport aux témoins. Dans le groupe I, la pectine provoque une chute significative de l'AFFe $: 25,5 \pm 5,0$ contre 47,6 $\pm 9,2$ à l'état de bas $(P<0,02)$. Au contraire la cellulose n'a aucun effet sur l'AFFe. Dans le groupe III, on note une baisse significative de l'AFCa $(P<0,02)$, du CMO $(P<0,05)$ et de la $25-O H-D(P<0,01)$ par rapport aux témoins. Nos résultats suggèrent que les régimes enrichis en fibres pourraient être utiles dans le traitement de l'hémochromatose. De plus, l'ostéopénie des hémochromatoses semble due à un défaut de production du $25-\mathrm{OH}$ cholécaciférol. De ce fait, une supplémentation en $25-\mathrm{OH}$ cholécalciférol peut avoir de l'intérêt pour prévenir la raréfaction osseuse. 


\section{References}

BIRGE S. J., PECK W. A., BERMAN M., WHEDON G. P., 1969. Study of calcium absorption in man : A kinetic analysis and physiologic model. J. clin. Invest., 48, 1705-1713.

BJORN-RASMUSSEN E., 1974. Iron absorption from wheat bread. Influence of various amounts of bran. Nutr. Metab., 1, 101-110.

BLUNT J. W., DE LUCA H. F., SCHNOES H. K., 1968. 25-hydroxycholecalciferol. A biologically active metabolite of vitamin D3. Biochemistry, 7, 3317-3322.

CAMERON J. R., SORENSON J., 1963. Measurement of bone mineral in vivo. An improved method. Science, 142, 230-232.

COOK J. D., LIPSCHITZ D. A., 1977. Clinical measurements of iron absorption. Clin. Haematol., 6, 567-781.

DELBARRE F., 1960. L'ostéoporose des hémochromatoses. Sem. Hôp. Paris, 36, 3279-3294.

DE LUCA H. F., 1974. Vifamin D. Am. J. Med., 57, 1-12.

HEATON K. W., POMARE A. W., 1974. Effect of bran on blood lipids and calcium. Lancet, i, 49-50.

ISMAIL BEIJI F., FARADJI B., REINHOLD J. G., 1977. Binding of zinc and iron to wheat bran and their components. Am. J. clin. Nutr., 30, 1721-1725.

MONNIER L., COLETTE C., AGUIRRE L., SANY C., MIROUZE J. 1978. Intestinal and renal handling of calcium in human diabetes mellitus., influence of acute oral loading and diabetic control. Europ. J. clin. Invest., 8, 225-231.

PREECE M. A., O'RIORDAN J. L. H., LAWSON D. E. M., KODICEK E., 1974. A competitive protein-binding assay for 25 hydroxycholecalciferol and 25 hydroxyergocalciferol in serum. Clin. chim. Acta, 54, 235-242.

REINHOLD J. G., FARADJI B., ISMAIL-BEIJI F., 1975. Fiber versus phytate as determinant of the availability of calcium, zinc, and iron in breadstuffs. Nufr. Rept. intern., 12, 75-85.

REINHOLD J. G., FARADJI B., ABADI P., ISMAIL BEIJI F., 1976. Decreased absorption of calcium, magnesium, zinc and phosphorus by humans due to increased fiber and phosphorus consumption as wheat bread. J. Nutr., 106, 493-503.

SHIPLEY R. A., CLARK R. E., 1972. Tracer methods for in vivo kinetics. Theory and applications. Acad. Press, 225-230.

WILLS M. R., 1973. Intestinal absorption of calcium. Lancet, i, 820-823. 